\title{
Evidence for laryngeal aspiration in Greek? Part I: The "recent" evidence
}

\begin{abstract}
Since de Saussure, H. Pedersen and Kuryłowicz the Sanskrit (and Indo-Iranian) voiceless aspirates are considered to be the result from the combination of a plain voiceless plosive and a laryngeal ( $* h_{2}$ according to most scholars), and, consequently, the existence of phonemic voiceless aspirates in PIE is no longer accepted. In more recent times, an evolution similar to that of Indo-Iranian has been assumed for Greek as well but the Greek situation is less convincing and has not been investigated as thoroughly as the Indo-Iranian branch. This article investigates the "recent" evidence in favour of the laryngeal aspiration in Greek (Peters 1993a and b, Werba 1996, Mayrhofer 2005, Matzinger 2005 and Vine 2006) and finds that most examples are not conclusive: either the reconstruction is not conclusive or there is an example under exactly the same circumstances that argues against aspiration. The older evidence (used by Sturtevant, Collinge, Hamp, Klingenschmitt and Isebaert) will be discussed in part 2.*
\end{abstract}

\section{The term "the recent evidence".}

In recent times the idea of Greek having undergone laryngeal aspiration as well has been slowly but steadily gaining acceptance. This article looks at the evidence used to support this assumption and starts by discussing the instances that have been quoted in the last 20 (the works being Peters 1993 a and b, Werba 1996, the LIV, Mayrhofer 2004 and 2005, Matzinger 2005 and Vine 2006). These instances are called "the recent evidence" and in part 2 we discuss the instances that were quoted in the older works (such as Sturtevant, Collinge, Hamp

* This article builds on a paper presented at the Conference "Greek and Latin from an Indo-European Perspective 3" where we analysed the Greek counterpart of Sanskrit th. Because of time constraints we could only discuss the issue of the laryngeal aspiration very partially. A detailed analysis of the evidence against the aspiration is planned for another occasion. We would like to thank Manfred Mayrhofer, Luc De Grauwe and Wolfgang de Melo (both Universiteit Gent), Michael Meier-Brügger (FU Berlin), Charles Barrack and Joe Voyles (UWashington) for their input and comments. It goes without saying that we are solely responsible for any inconsistencies and shortcomings. 
and Klingenschmitt 1982). This distinction is solely based on practical reasons as treating all the examples at once would make the article much too long.

\section{The evidence in favour of laryngeal aspiration.}

1. oĩ $\sigma \theta \alpha$ (communis opinio), Sanskrit vettha, Latin vīdistī. This example is the most commonly accepted as evidence for the aspiratory effect of $* h_{2}$ in Greek and is quoted in almost every handbook. It is therefore not really recent evidence, but as it is used by recent scholars, we believe it is useful to include it in part one of the discussion. The reconstruction of the second person perfect as $* t h_{2} e$ goes back to Kuryłowicz (1927:202-204, 1927/8:103) and was based on the parallel reconstruction for the first person singular $* h_{2} e$. An additional argument for the reconstruction with a laryngeal is the Hittite $2^{\text {nd }}$ person ending $t i$ without palatalisation, which meant that there was another consonant between the $t$ and the $i$ because otherwise the ending would have been * $z i$ (Kuryłowicz 1927/8:103 and later also Pedersen). As such, a perfectly balanced schema in the singular perfect was obtained: ${ }^{*} h_{2} e,{ }^{*} t h_{2} e$ and $* e$. We admit that this is the most convincing example for the assumption of laryngeal aspiration in Greek, but the idea of laryngeal aspiration in Greek is still considered by several scholars to be unlikely (this assumption started with Kuryłowicz himself (1935:52), was followed by Cowgill 1965:171 and Ruijgh 1978:302 and seems even to be accepted by Vine 2006:290), ${ }^{1}$ and there are two alternative suggestions for this form. ${ }^{2}$ Ruijgh

1 Kuryłowicz tried to explain the aspiration by assuming that Greek *ta became tha in contexts where *ta came in contact with an aspirated root consonant (as a sort of Bartholomae's Law in Greek) and was then generalised as perfect ending before it was supplanted by the ending as. While Kuryłowicz later rejected almost all his laryngeal theories, he did not recant his explanation for the Greek aspirate in the ending tha. Cowgill (1965:171) argued for an ending *sta: the cluster *uoidsta became *uoidtha (loss of $s$ and subsequent aspiration of $t$ ) and then oĩ $\sigma \theta \alpha$. Cowgill was followed in this by Sihler 1995. Vine, who accepts laryngeal aspiration for Greek, nevertheless writes about the tendency of Greek to generalize unaspirated stops in forms from a sequence $\mathrm{Th}_{2} \mathrm{~V}$ " (2006:290).

2 A complete discussion of this form would lead us too far and will be done at another occasion. We deal here with the most common suggestions. 
(1978:302, review of Rix 1976) argued that while the Sanskrit form vettha could be explained from *uoidth $h_{2} e$ with laryngeal aspiration, the Greek form oĩ $\sigma \theta \alpha$ could not, and therefore suggested that the Greek aspiration came from the imperative form 'o $\sigma$ l (from PIE *uiddhi). ${ }^{3}$ The other alternative suggestion was made long before the laryngeal theory already and stated that the PIE ending was * $t^{h} a$ with a genuine phonemic voiceless aspirate,${ }^{4}$ but that reconstruction is no longer accepted. We would like to address the argument made by Kuryłowicz that Hittite $t i$ proved that the ending was $* t h_{2} e$. We believe that this argument is convincing but not conclusive: if the ending had been ${ }^{*} t^{h} a$, there was no front vowel before the $t$ and hence no reason for assibilation. While we personally prefer the reconstruction $* t^{h} a$, we cannot rule out the reconstruction $* t h_{2} e$. The form oĩo $\theta \alpha$ is therefore a good candidate for laryngeal aspiration in Greek, but it is not

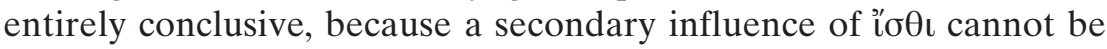
excluded.

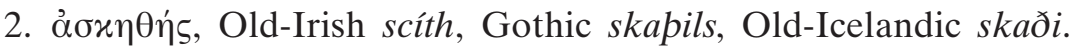
Klingenschmitt (1982:83), followed by Matzinger (2005:47), suggested that there was a noun ${ }^{*} s k e h_{1} t h_{2}$ os that disappeared in Greek but that lead to the creation of adjective *skeh $t_{1}$ es which became Greek * $\sigma x \eta \theta \eta$ '. The opposite of this (not attested) adjective was $\dot{\alpha} \sigma x \eta \theta \eta$ ' 5 and was preserved whereas the noun and original adjective disappeared. ${ }^{5}$ Rasmussen (1989:154) rejected the reconstruction *skeh ${ }_{1} t h_{2} o s$ a because of the Celtic form: a form with a laryngeal would have created Proto-Celtic *scitathud which should have given *scithud. Therefore the reconstruction has to be ${ }^{*} s k e h_{1} t^{h}$ os. Even scholars who do not accept the existence of phonemic voiceless aspirates for PIE, acknowledge that these cognates nevertheless point at PIE *th (Mayrhofer 1986:98, 2004:44;6 Meier-Brügger 2003:125;

3 This was based on an explanation of Frisk's (1936:43), who assumed that PIE *uoidt ${ }^{h}$ a gave Greek *oista which became oĩ $\sigma \theta \alpha$ under the influence of ' $\sigma \theta$.

${ }^{4}$ See among others Graßmann 1863a:98; Brugmann 1886:407, 1889:1341-1342; Chantraine 1933:365-368,1945:350; Austerfjord 1979:212; Szemerényi 1980:62-63 and 306, Bammesberger 1984:96-98, Elbourne 1998:18, Lazzeroni 1998:115.

5 The normal attested Greek opposite of $\alpha \sigma x \eta \theta \eta \dot{\varsigma}$ is $\alpha \dot{v} \alpha \sigma x \eta \theta \eta \dot{\varsigma}$, but that form is only attested as of IVa in Tegea.

6 Stating that Mayrhofer did not accept voiceless aspirates is not entirely correct. In his works of 1986, 2004 and 2005 he stated that he accepted a very small series of expressive and/or affective words with voiceless aspirates, but that he did so 
Clackson 2007:42-44). This form can therefore not be used as evidence for laryngeal aspiration in Greek.

3. xó $\chi \chi 05$ is linked with Sanskrit sankhah and Latin congius (if this is not a loanword from Greek). ${ }^{7}$ These cognates have been used to prove that $* h_{2}$ also aspirated in Greek and as a result the reconstruction of this noun was *konkh $h_{2} O s$. This reconstruction has been accepted by many scholars such as Mayrhofer (2005:113 with doubts and against his view of 1986:98 and 2004:44). This noun was originally reconstructed as $k^{\prime} o n k^{h} O{ }^{8}{ }^{8}$ Mayrhofer considered this noun to be a "Wanderwort" and a "Kulturlehnwort". There seems to be no evidence in Greek that effectively speaks against the cluster * $k h_{2}$, and this noun could be another example that could prove aspiration in Greek. The first problem is the fact that this etymology seems to have $* h_{2}$ in it only to rid PIE of a voiceless aspirate, and that the assumption of a suffix $* h_{2} O$ seems to be rather $a d h o c$. If one accepts the existence of a suffix $* h_{2} O$, the question remains why the aspiration is not visible in the superlative suffix $* i s-t h_{2} O s$ and the cardinal suffix $* t h_{2} O s$. A second, and in our opinion more important, objection is the lack of aspiration in Greek word oxió, which can be reconstructed as ${ }^{*} s k h_{2} i e h_{2}$ and linked with Sanskrit chāy $\bar{a}$ (which would be formed on the full grade $\left.* s k e h_{2} i h_{2}\right)$. Mayrhofer (2005:51) only reconstructed $* k H$ and did not discuss the absence of the Greek aspiration. That absence is in our opinion an argument against the assumption of a cluster $* k h_{2}$ in xó $\chi 05$, because one would then have to explain why under exactly the same circumstances Greek displayed two different treatments of the cluster $* k h_{2}$.

merely out of typological necessity because languages with voiced aspirates but without voiceless aspirates are very rare. That issue cannot be dealt with either. It has to be stressed that Mayrhofer accepted the existence of laryngeal aspiration for Greek and pointed explicitly at Peters's list of 1993a and b.

7 Latin congius seems to be a loanword from Greek, although Ascoli (1868b: 327-330) suggested an evolution from PIE *konk $k^{h}$ os into Proto-Latin *conhos which later became *congus. The ending ius was taken over from modius: Ascoli argued that because congius was used as a measurement tool, it received the ending of another similar instrument, modius.

8 Graßmann 1863a:98; Wackernagel 1894:119; Uhlenbeck 1898a:301, 1898b:67; Grammont 1948:179; Szemerényi 1980:62-63; Elbourne 1998:8, Meier-Brügger 2003:125, Mayrhofer 2004:44. 


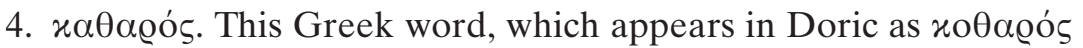
and in Boeotian as $x$ ó $\theta \propto \varrho o \zeta$, is linked with the Sanskrit adjective sithirah and the verbal form śrathayati, and has been reconstructed as * krth ${ }_{2}$ ros. The link between these two adjectives was already made at an early stage (see e.g. Macdonell 1916:250). Kuryłowicz (1928:55-56) explained the aspiration in the Sanskrit verbal forms as the result of a cluster $* t h_{2}$. Peters (1993b:95-98) expanded this analysis and also considered the Greek aspiration to be the result of $* t h_{2}$. In order to account for the lack of an $r$ in the first syllable of the Greek word he assumed a dissimilatory loss of the $r$ in the first syllable. The idea of dissimilatory loss of $r$ in Greek is not new, as already Wackernagel

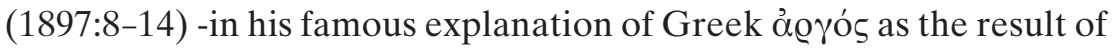
dissimilation of *argros - and later also Grammont (1948:164-166) and Lejeune (1972:150) discussed this phenomenon and listed the occurrences. Vine (ftc) built on the preceding analyses and pointed at the presence of dentals in most cases of dissimilation, such as the Cre-

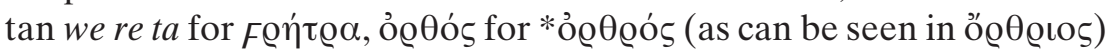
and argued that the form $\varrho \alpha \tau \varepsilon \varrho o ́ s$ was also the result of a dissimi-

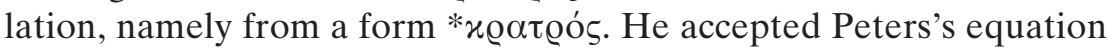
but added that the form nevertheless posed some problems as to the chronology. Pointing at the Sanskrit verbal form śrathayati, Peters (1993b:95-98), Hackstein (2002:212-213) and Mayrhofer (2005:75) argued that Sanskrit had also undergone the dissimilatory loss in the adjective but that the $r$ was present in Indo-European and Proto-Sanskrit. There are parallels for the evolution in Sanskrit. Narten (1982:140), and later also Lubotsky (1995:136), analysed the Sanskrit forms durhanā as the result of dissimilation from *durhrnā, muhur as dissimilation from *mrhur and sithira- as the result of earlier *śrthira-. The link between Greek $k$ and Sanskrit ś points at a palatal $k$. The result śr from $* k r$ is an apparent exception to Weise's Law which states that $* k r$ became $k r$ in Sanskrit while *kl became śr (Weise 1883:115-116). Kloekhorst (ftc) fine-tuned this law to state that $* k r$ became $s r$ if there were case forms where the $* k$ and $* r$ were not contiguous (an observation already alluded to by Weise himself, see 1883:115). This explains why zero grades of roots in *ker have a palatal ś in forms going back to *kr, while they should not have this according to Weise's Law. Another specification by Kloekhorst was that * $k r$ became s $r$, if the vowel following the cluster was an $i$. Kloekhorst added that this palatal $s$ could then be extended to cases in the para- 
digm where it was not etymological (examples can be found in Kloekhorst $\mathrm{ftc}$ ). The $i$ in this adjective is not of PIE date but an evolution of Proto-Indic where the sonantic liquids were rendered as $r i$, $r a$ or $r u$ depending on the following vowel. As such, this seems to be an exception to the Law. In our opinion this is only an apparent exception because the full grade śrathayati can be reconstructed as *kreth ${ }_{2}$ eie/o, which has a palatal vowel in the first syllable (for the reconstruction with $e$ see Jamison 1983:178 but for $o$ see Peters 1993b, Hackstein 2002:212-213). As such we would add an additional aspect to Kloekhorst's adaptation of Weise's Law, namely that PIE * $k r$ becomes $s r,{ }^{9}$ if * $k r$ is followed by a palatal vowel. The sibilant of the full grade was then analogically extended to the zero grade where it should not have appeared. As such, the first objection against the linking of the Sanskrit and Greek words has been addressed. Kloekhorst himself rejected the Indo-European heritage of the Sanskrit word (but he did not explain why as he only stated that $*$ kroth ${ }_{2}$ eio or $* k r e t h_{2}$ could not be the correct reconstruction) as did Beekes 2010. The second objection against the link between the Greek and Sanskrit forms is the fact that Sanskrit has forms with an $r$ while Greek does not. The $o / a$ of $x \alpha \theta \alpha \varrho o$ contradicts the treatment of $* r$ in Greek: this is not $o$ or $a$, but rolor or ralar. This apparently anomalous treatment of * $r$ is explained by the assumption of dissimilatory $r$ loss (cf. supra). The evidence of the $r$ dissimilation in Greek, as compiled by Grammont 1948, Lejeune 1972 and especially Vine ftc, is diverse, but some observations can be made. First of all, since Doric, Aeolic and Ionic-Attic are believed to have undergone this dissimilation, one is tempted to assume that this process occurred at Proto-Greek level, but the fact that Doric and Aeolic have an $o$ and Ionic-Attic has an $a$ indicates that the dialects dissimilated independently after the Proto-Greek period. The Proto-Greek structure is $C r . C V . r V$ (assuming that the laryngeal was already vocalised) with the first $r$ being syllabic and belonging to the first syllable and the second $r$ being consonantic and belonging to the third syllable. The objections against the syllable structure *kr tha ros

9 The words of these family -if they belong to the same family at all- only appear in Greek and Sanskrit. As such, we believe that the assumption of an IndoEuropean heritage is not certain. This could be another Graeco-Aryan isogloss, and therefore the reconstruction better be described as Eastern-Indo-European (this term is a coinage based on Wolfgang Meid's "Ostindogermanisch"). 
in Proto-Greek are in our opinion not convincing. The forms

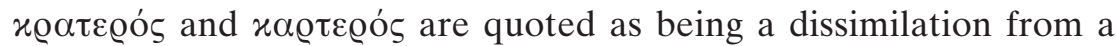
proto-Greek form *krtros, but even if we accept that their structure was *krtros, that structure is still different from * $k r$ tha ros. Moreover,

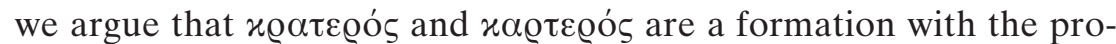
ductive suffix (t)eros and prefer Proto-Greek *krteros as reconstruc-

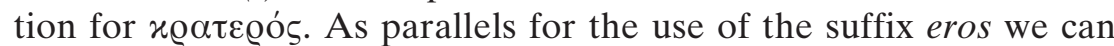

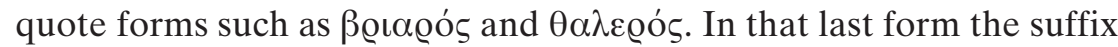
is clearly *eros because with a suffix * ros the forms would have been ${ }^{*} d^{h} h_{2}(e)$ lros which would have yielded *thalaros. ${ }^{10}$ As such, we see no difference between the structure of *kratharos (the supposed

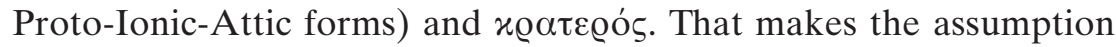
of dissimilation in $x \alpha \theta \alpha \varrho o$ s less likely. Finally, and more fundamentally, we believe that both $x \alpha \theta \alpha \varrho o ́ s ~ a n d ~ x \alpha \theta \alpha i \varrho \omega$ are at odds with the suggested evolution $* t_{2} V$ into $t^{h} V$ as neither form has the environment $* t h_{2} V: x \alpha \theta \alpha \varrho o ́ \varsigma$ is said to originate from $* k r t h_{2}$ ros (Peters 1993b:95-98) while $x \alpha \theta \alpha i$ i $\omega$ comes from $* k r t h{ }_{2} r$ - ie/o, with the verb being a deverbative from the adjective (and hence a secondary form). ${ }^{11}$ Peters (1993b:96) argued that the Greek lack of aspiration in $\pi \lambda \alpha \tau$ ' $\varsigma$ was caused by the fact that the feminine form ${ }^{*} p l t h_{2} u i h_{2}$ and the derivative $*$ plth ${ }_{2} m \bar{o} n$ did not have the environment $* t h_{2} V$, and that from those forms the non-aspirated form was generalised throughout the entire paradigm, but the adjective $x \alpha \theta \alpha \varrho o ́ s$ does not display this environment either but nevertheless underwent aspiration. As such, the evidentiary weight of the adjective $x \alpha \theta \alpha \varrho o ́ s$, which was already lessened by the absence of the $r$ in the first syllable, is in our opinion

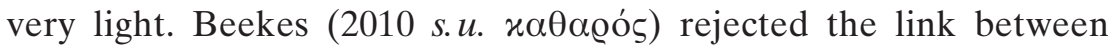
Greek and Sanskrit because of the treatment of the * $r$ and because of the laryngeal aspiration (an idea he disagreed with), and considered

10 Greek also had a productive suffix aros (Chantraine 1933:227).

11 With regards to the Sanskrit forms we have two observations to make which do not have any direct bearing on the issue of laryngeal aspiration in Greek. First of all, we believe that the existence of the Sanskrit form sithirah is in itself no evidence that Sanskrit underwent the same dissimilation as Greek. Although this form is widely attested in the manuscript tradition and therefore should receive preference, it cannot be ruled out that this form is a Prakritism. The evolution of śri into śi is widely attested in the transition from Old-Indic into MiddleIndic (Macdonell 1910:7, Van den Bossche 1999:14 with specific reference to this form). 
the Greek word to be of pre-Greek origin because of the a/o variation in the different dialects.

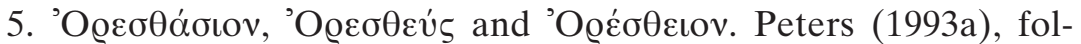

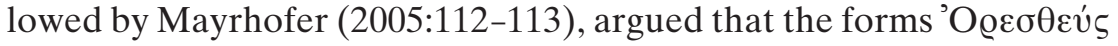

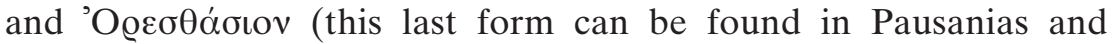
Stephanos from Byzantion) were evidence that in Proto-Greek the root $* s t e h_{2}$ had aspiration in the forms where the sequence $* T h_{2} V$ occurred. He started from a noun *ores-steh ${ }_{2} s$ "having his place in the mountains". The genitive and dative singular of this noun would have been *ores-sth ${ }_{2} O s$ and *ores-sth $2 e i$. These forms initially displayed aspiration, but lost it at a later stage under the influence of the nomi-

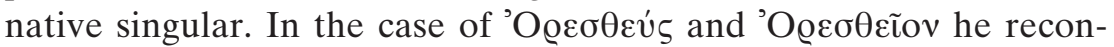
structed $*$ oresth $_{2} e$ - and argued that the sequence $* T h_{2} V$ was rendered by $T h V$ without colouring effect of $* h_{2}$. This theory was accepted by Mayrhofer (2005:112-113). While Peters (1993a:137 with reference to Hiersche) did not rule out that the aspirated forms, which came from Boeotia, were the result of hypercorrections (as the dialects spoken in that area had a tendency to render $s t h$ by $s t,{ }^{12}$ it is possible that in some cases they wrote a "correct" sequence $s t$ by $s t h$ ) he nevertheless called his suggestion for laryngeal aspiration "nicht zwingend, aber plausibel". We believe that there are some remarks that can be made about these forms. The more likely explanation for the form 'O@ǵ $\sigma-\tau \bar{\alpha} \varsigma$ is in our opinion ỏ@ź $\sigma-\tau \bar{\alpha} \varsigma$ "the man in the mountains", such as $\pi$ o $\lambda i \tau \alpha \varsigma$ is $\pi \circ \lambda i-\tau \bar{\alpha} \varsigma$ "the man from the city". There is no such noun as "standing

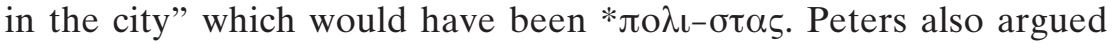
that the original declension was nominative ${ }^{*}$ oreste $_{2} s$ and genitive * oresth ${ }_{2}$ os. There is no parallel for such a declension in Greek and the only other adjectival derivation built directly on the root $* s t e h_{2}$ is

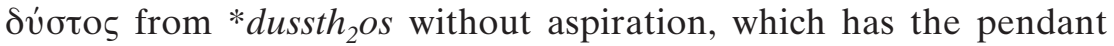
duhthah in Sanskrit (with aspiration). One can also point out that

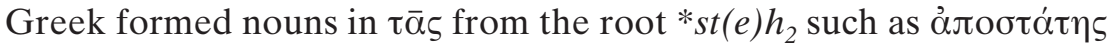
(although one could argue that these formations were secondary). In addition, the masculine nouns in $\tau \bar{\alpha} \varsigma$ follow the first declension (with exception of the genitive singular, which in all likelihood was an

12 For an entirely different approach to the writing $\sigma \tau$ and its meaning see already Thumb 1913, who argued that the writing of $\sigma \theta$ by $\sigma \tau$ in fact proved that the pronunciation of $\theta$ in this context was not fricativised in that context and therefore assumed that the pronunciation of $\sigma \theta$ was still sth. 
innovation of Greek to distinguish the masculine form the feminine nouns, see Chantraine 1945:41). ${ }^{13}$ Secondly, -as Peters already pointed out himself- the suggestion of a hypercorrection cannot be excluded. Given that North-West dialects usually rendered Greek sth by $s t$ (Schmitt 1977:29), it is possible that in one instance they rendered a correct $s t$ by $s t h$. For a parallel one can point at the correct plodere which was rendered in Vulgar Latin as plaudere. Peters nevertheless argued that in spite of the possible hypercorrection the name was still probative. More important in our opinion is the link with the name

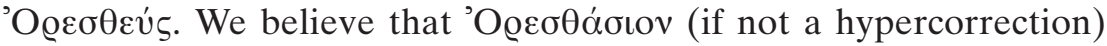

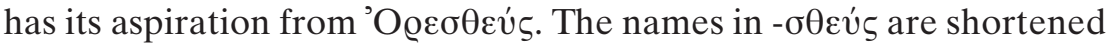
forms from - $\sigma \theta \varepsilon \dot{v} \eta{ }_{5}$ with a negative connotation (Ruijgh 1967:193, 256-257, Perpillou 1973:176-177, Aura Jorro 1999 I:86, II:235). The meaning and negative connotation are in fact confirmed by the story: Orestes does not receive his force from the mountains and only avoids death by the hands of his mother and Aigisthos by sending them the false message that he has died during a chariot race. In the vengeance of Agamemnon not he but Elektra is the main protagonist: she sends Orestes away, she hides him and she provides him with the dagger to enact the murder of Aigisthos and Klytaimnestra. In addition, Orestes can only avoid the wrath of the Erinyes by explicit intervention of Athena. As such, Orestes has no strength of his own and the name "having strength from the mountains" has a negative connotation. Parallels can be made with the mythical king Eurystheus ("having strength over a broad region") and Menestheus ("having a forceful nature, strength") whose names in - $\sigma \theta \varepsilon \dot{\varsigma} \varsigma$ were also clearly pejorative. Eurystheus only obtained his power by a trick of Hera and in spite of him commanding Herakles, he was nevertheless infinitely inferior in force and courage to Herakles. Menestheus was characterised in the Iliad as being non-valiant and avoided battle action as much as possible and was even chastised by Agamemnon for staying away from the frontline (Iliad 1,338-348 and 12,331-334). We agree with Mayrhofer (2006:11, although he only made this link implicitly) that the name

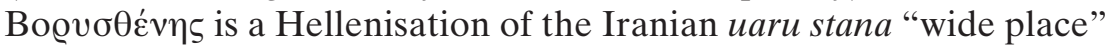
but we believe that the aspiration in this name is due a folk etymologi-

13 Chantraine assumed that the nominative ending $-s$ was another "diversifier" but it is not certain that this was a Greek innovation or a feature already present in PIE. 
cal link with $\sigma \theta \dot{\varepsilon} v o \varsigma$ "strength" and with other names in - $\sigma \theta \dot{\varepsilon} v \eta \varsigma$, and has nothing to do with the root *steh $2^{-}$. Given the fact that the Greek had contact with the Scythians in the north, this name can also be explained as a reinterpretation "strength from the north" with Bo@v- re-

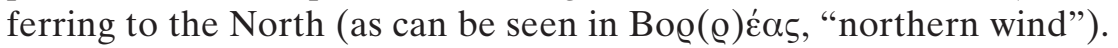
The fact that an Iranian $a$ is rendered by a Greek $e$ should make one cautious as to consider the aspiration an inherited aspirated feature. A final argument that we have against the assumption of a root ${ }^{s} t h_{2} e$

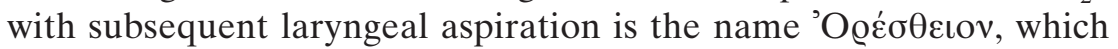
Peters reconstructed as *ore-sth 2 eion. The Greek reflex of $* t h_{2} e$ is $t a$ or tha if one accepts aspiration, but not the as $* h_{2}$ colours $* e$ into $* a$. This is proved by the place name $\Pi \lambda \alpha \dot{\tau} \alpha \iota \alpha$, which is related to $\pi \lambda \alpha \tau \dot{v} \varsigma$ and can be reconstructed as ${ }^{*}$ plth ${ }_{2}(e) i a$. We therefore do not think that these examples can be used to prove aspiration in Greek.

6. $\mu$ ó $\theta$ os. This word is related to Sanskrit manthäh, the verb manthati and its participle mathita. The Indic grammarians pointed out that the declension of manthāh followed that of panthāh were similar (see Whitney $§ 434$ and Polomé 1965:42). Kuryłowicz (1927/8:202-204) analysed this verbal form as $* m^{*}$ nth $_{2}$ and this reconstruction is now accepted. As Sanskrit also had forms such as mathati and manthati, it has been suggested that the root $*$ menth ${ }_{2}$ could also appear as

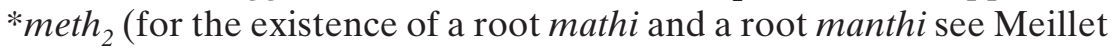
1928b:284-285). ${ }^{14}$ One could argue that this $n$-less form is a backformation on the participle mathita. The Greek form is reconstructed as * moth $\mathrm{Os}$, and the cluster $* t h_{2} \mathrm{O}$ is then considered the reason for the Greek aspirate th. Others (since Kuiper 1934:104) have suggested that the Greek form went back to *mnth ${ }_{2} O s$ and that the $o$ was the Aeolic treatment of the sonantic $n$, but the same explanation was used to explain the Greek th (namely the cluster $* t h_{2} o$ ). Other related forms are OCS motati, Latin mentula and Old-Icelandic mondull (Kluge 1883:89), although not all cognates (especially the Old-Icelandic one) are accepted by all scholars. If the reconstruction *menth ${ }_{2}$ is used as starting point, Sanskrit manthăh is built on $*$ menth ${ }_{2}{ }_{2} h_{2}$ and Greek $\mu$ ó $\theta$ os on $* m(o) n t h_{2} O s$. As such, the aspiratory effect of $* h_{2}$ in Greek seems an established fact. The difference in between Sanskrit panthāh

14 Narten (1960:134-135) assumed that the root was math without nasal infix and that the original meaning was "rob". She linked the root with Greek (Doric) П@o$\mu \alpha \theta \varepsilon v \dot{s}$. This suggestion has not found general acceptance (see Peters 1993b:97). 


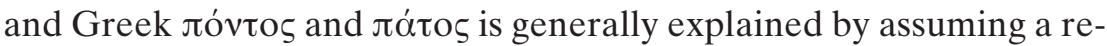
construction * pento $h_{2} s$ for Sanskrit and *pontos for Greek. About this apparent difference in root formation, some observations can be

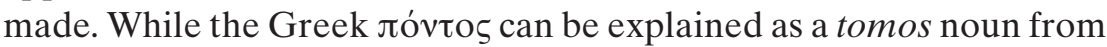
a root *pent, this is more difficult for лótos. That form has to be formed on the zero grade case forms which go back to *pnth ${ }_{2}$ The proto-form would therefore have to be *pnth $\mathrm{Os}$, but the Greek word does not show any traces of aspiration. Given the parallel formation between Sanskrit panthāh and manthāh on the one hand, and on the

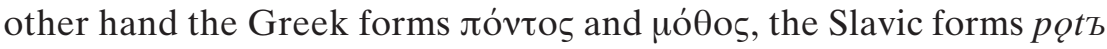
and motati, the Latin form pons, and the Armenian form hun, we would reconstruct * pontoh $h_{2} S$ and $* m o n t^{h} O h_{2} s$, both with an *o vowel in the root (as is confirmed by the nouns from Greek, Slavic, Armenian and Latin) and with $* o$ in the suffix. ${ }^{15}$ This is not a generally accepted ablaut paradigm, but it is paralleled in $s a k h \bar{a}$ from ${ }^{*} s o k^{w} h_{2} O i$ and in sakhibhih from ${ }^{*} s k^{w} h_{2}$ bhis (the reconstruction can be found in Mayrhofer 2005:114). The Latin cognate socius has generalised the zero grade of the suffix $* o i$, namely $i$ and has then thematicised it (as Schmidt 1885 already argued) ${ }^{16}$. Moreover, we would like to point at the Sabellic treatment: Latin has mamphur which is probably a loanword from a Sabellic language in Latin (Walde 1905:459, Hoffman 1950:209) and displays the typical Sabellic treatment of an IndoEuropean aspirate in inlaut, namely a voiceless fricative. In spite of

15 We come back to this later but would already point out that in our opinion the nominative and accusative plural of these $-\mathrm{Oh}_{2} \mathrm{~s}$ nouns were the driving force to attract these nouns into the thematic $o$ stems. A form *pontoh ${ }_{2} e s$ would have become Proto-Greek *pontōs and looked the same as the nominative plural of the thematic $o$ stems. The accusative form * ontoh $_{2} n s$ would -with Stang's Lawhave become *pontōns and then in late Indo-European *pontōs. In Proto-Greek the $n$ would have been reintroduced into the accusative plural (as happened with the $* e h_{2}$ nouns) and then the form *pontons would have become *pontons by the effects of Osthoff's Law. As such also the accusative had the same form as the thematic $o$ stems. We refer for more details to De Decker ftc b and c.

16 In De Decker ftc a we tried to argue that the Sanskrit panthăh, the Armenian $h u n$, and the Old-Persian p $\theta i m$ were no indication of an $i$ stem, be it original (as Schmidt 1885, Bezzenberger 1908 and Hirt argued) or secondary (as Beekes 1989, Schrijver 1991, De Vaan 2008 s.u. pons en Derksen 2008 s.u. pontb argued). We nevertheless do not think that Pedersen's reconstruction (*pon$t e h_{1} s$ ) can be sustained (see previous note). We admit that this is problematic for Latin, but will treat the issue more in detail elsewhere. 
the objections raised above, the reconstruction $* m o(n) t h_{2} o s$ cannot be ruled out and this form can still be considered an example of laryngeal aspiration in Greek.

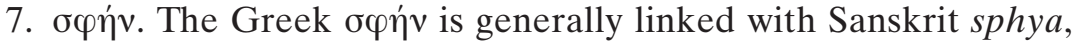
Germanic spade and maybe also spoon. The Sanskrit form sphya can be reconstructed as * $s p h_{2}$ iio (Mayrhofer 2005:82, without mentioning the Greek $\sigma \varphi \eta v)$, but $\sigma \varphi \eta v$ has to be reconstructed as *speh ${ }_{2} e n$ or ${ }^{*} \operatorname{speh}_{2} n$, as in non-Attic dialects the form is $\sigma \varphi \bar{\alpha} v$ (Schulze 1913, Wahrmann 1915b:164). The Germanic cognates are not so easily reconstructed, however. While spade can be linked with the root ${ }^{*} s p(e) h_{2}(e)$ - (as it goes back to $*^{*} p h_{2} d^{h_{-}}$, as does Greek orá $\left.\theta \eta\right)$, English spoon and Old-Icelandic spān are more problematic because they go back to a Proto-Germanic form *spenn-and this reconstruction is difficult to reconcile with the Greek $\bar{a}$ vocalism (Schulze 1913).

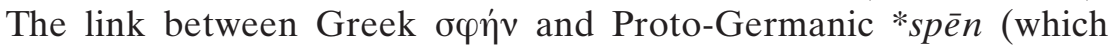
goes back to Kuhn 1854$)^{17}$ is therefore not accepted by every scholar (the etymological dictionaries of Frisk, Chantraine and Beekes rejected the link). ${ }^{18}$ Vine (2006:290) attempted to solve that difficulty by starting from a form ${ }^{*} \operatorname{speh}_{2} n$ (and based on a suggestion of Sergio Neri's on a form * $s p h_{2} e n$-). That form was the basis for a lengthened grade nominative ${ }^{*} \mathrm{sph}_{2} \bar{e} n$ in Indo-European. In that nominative form $* \bar{e}$ was not coloured by the contiguous $* h_{2}$ as the result of Eichner's Law (Eichner 1972), and Vine assumed that the lengthened grade of the nominative was spread throughout the entire paradigm. This lead then to the creation of a Proto-Germanic form *spenn. For Greek a nominative $* s p(e) h_{2} e n$ was suggested. The cluster PIE $* e h_{2} e$ yielded $* \bar{a}$, which was the basis of the Proto-Greek $* \bar{a}$ and the aspiration in

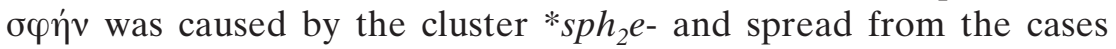

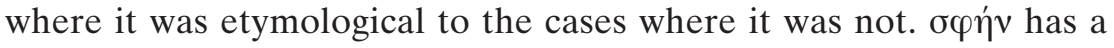
genitive $\sigma \varphi \eta v o ́ s$ and (as was already stated above) appears in other dialects as opóv and therefore has to go back to Proto-Greek *sphān-. In order for the Greek declension to be explained, one has to reconstruct $*_{s p e h} n s$ for the nominative and $*^{*}$ speh $_{2}$ nos for the genitive. In that case there is no environment where the aspiration could have oc-

17 Kuhn's articles of 1852,1854a and b dealt with the aspirating effects of an initial $s$ sound in Greek, Sanskrit and Indo-European.

18 For an analysis of the previous suggestions and etymologies see Vine 2006:289-292. 
curred, unless one assumes a paradigm ${ }^{*} s p h_{2} e n s$ in the nominative and ${ }^{*} s p h_{2}$ nos in the genitive with generalisation of the full grade and the aspiration in the nominative throughout the paradigm. We admit that it is difficult to prove or disprove paradigmatic levelling but we would argue that the generalisation of the lengthened grade was a feature of the nominatives in predominantly found with the nominatives in $\omega v$, with the nomina agentis in $\omega v$ being an exception with a nominative in $\omega \dot{v}$, but a genitive in óvos as can be seen in i் $\gamma \varepsilon \mu \omega ́ v$, iं $\gamma \varepsilon \mu$ óvos. The nouns in $\eta v$ have a nominative in $\eta v$, but the casus obliqui are built starting from $\varepsilon v$-, unless the long vowel is an inherited feature (as is the case in $\mu \eta \dot{v} v$, genitive $\mu \eta v$ ó $\varsigma$ from *meh ${ }_{1} n-s$.). A good example is provided by the cognates $\lambda \mu \mu \eta \dot{v} v$, genitive $\lambda \iota \mu \varepsilon \dot{v}$ os and $\lambda \varepsilon \iota \mu \omega ́ v$, genitive $\lambda \varepsilon \iota \mu \tilde{\omega} v o s$ (see Schindler 1967:201-202). As such, we would reconstruct $* \operatorname{speh}_{2} n$ - for the entire paradigm and in that case the context for the laryngeal aspiration is no longer present. As it cannot be excluded that Greek generalised the long vowel from the nominative, we admit that this noun could be proof of laryngeal aspiration in Greek but we nevertheless have some problems with the assumption of the generalising of the aspiration.

8. $\sigma \varphi \alpha \dot{\lambda} \lambda \lambda \omega$. A convincing etymology of this Greek verb has not yet been found. Greek $\sigma \varphi \alpha \dot{\lambda} \lambda \omega$ was first linked with Sanskrit skhalati and Armenian sxalem by Hübschmann (1882:119, 1883:81, 1897:49). Since Greek has a labial and that Armenian and Sanskrit have a plain velar, a reconstruction with a labiovelar has been suggested. Because of the Greek and Armenian $a$ the Indo-European vowel cannot have been $* o$ nor $* e$ and had to be either $* a$ or $* h_{2} e$ (depending on the acceptance of an Indo-European phoneme $* a)$. Based on this set of cognates some scholars have argued for a root $*_{s} k^{w} h_{2} e l$ - (Klingenschmitt 1982:144, Werba 1997:383, Mayrhofer 1996:752) in which the cluster $* s k^{w} h_{2} e$ would have caused aspiration in Greek, Armenian and Sanskrit. In light of Siebs's Law (Siebs 1900) the suggestion was made that these words illustrated the Law and, consequently, *sgwh $h_{2}$ el (LIV:543-544, Mayrhofer 2005:114- without Indo-European *a) and $*^{*} g^{w h} a l$ (with $* a$ ) were proposed as etymologies. Also a "straightforward non Siebsian" *skwhal was reconstructed (Grammont 1948:183). We believe that the laryngeal $* h_{2}$ has been reconstructed in this form only because many scholars not longer accept the existence of a phoneme $* a$. The genuine Indo-European $* a$ in this word can be explained by de Saussure's suggestion that words with an $* a$ referred to 
negative characteristics and disabilities. ${ }^{19}$ Consequently, we do not see why a reconstruction ${ }^{*} s g^{w h} h_{2} e l$ should be preferred over a reconstruction *sgwhal. Given the fact that voiceless aspirates more than in other words appeared in words referring to deficiencies or lower words (Meillet 1930, Mayrhofer 1986:98), the reconstruction could also be *sk ${ }^{w h}$ al (against the objections raised by Clackson 1994:144). In spite of the $a$ vocalism of Greek and Armenian, a link with Latin scelus and Gothic skulan has been suggested, ${ }^{20}$ and an etymology ${ }^{*} s k^{w h} e l$ was proposed (Elbourne 1998:11). ${ }^{21}$ Elbourne explained the irregular treatment of PIE *e by Armenian $a$ by pointing at Armenian tasn from *dekm. In that scenario Armenian $a$ was an irregular reflex of $\operatorname{PIE} * e$, Latin $e$ was the regular outcome, Sanskrit $a$ displayed the regular treatment of PIE *e and Greek $\sigma \varphi \alpha \dot{\lambda} \lambda \lambda \omega$ was built on the zero grade $* s k^{w h l-i o h_{2}}$, as in $\beta \alpha \dot{\alpha} \lambda \lambda \omega$, from zero grade $* g^{w} l-i o h_{2}$. If these etymologies are correct, there would be no trace of any laryngeal at all, but we think that the Indo-European heritage of the * $a$ is rather certain by the fact that this word refers to a negative trait. We, nevertheless, have a slight preference to link $\sigma \varphi \alpha \dot{\lambda} \lambda \omega \omega$ with Armenian p'lanim, English fell and fall, and Latin fallere, and maybe also Albanian fal, ${ }^{22}$ and would like to return to the reconstruction * $(s) p^{h} a l-23$ with an IndoEuropean voiceless aspirate, ${ }^{24}$ an Indo-European $* a$ and $s$ mobile in

19 De Saussure made this assumption in 1912 article Les adjectifs du type caecus "aveugle" (the text can be found in Bally-Gautier 1922:595-599).

20 Brugmann 1888:406, Uhlenbeck 1896:130, Feist 1888:104 suggested *sqhel. Brugmann included the Greek forms, but Feist and Uhlenbeck did not. Scardigli (1973:33) followed Feist and Uhlenbeck and reconstructed $*(s) k(h) e l$ without labiovelar.

21 Seebold 1980:483 suggested it but was not entirely certain. Elbourne (1998:11) on the other hand suggested $*^{*} k^{w h} e l$ and did not make the link with neither the Gothic nor the Latin forms.

22 Çabej 1980:44 referred to Barić and suggested that Albanian $f$ could be a reflex of PIE $* p^{h}$. Holst 1998 considered Albanian $h$ to be a reflex of PIE $* p^{h}$, but did not discuss $* s p^{h}$.

23 This etymology was already suggested by Ascoli 1868b:326 - without the Armenian form- and defended by Kluge 1882:526, 1899:103; Bugge 1893:28, Meillet 1894:294 and Grammont 1948:289 who in fact argued for both etymologies in his book. Graßmann (1863a:96-98) linked all the words (with exception of Albanian and Armenian) and assumed that in PIE there was an interchange of $* k^{h}$ and $* p^{h}$ possible after $*_{s}$.

24 Curtius (1873:334-335) listed the Greek, Sanskrit, Latin and Germanic cognates but reconstructed *spal, without aspirate. 
Greek. ${ }^{25}$ Although we would personally suggest $*(s) p^{h}$ al as etymology, there is no solid ground to reject the etymologies ${ }^{*} s k^{w h} a l$, * $s g^{w h} h_{2} e l$ or * s $g^{w h} a l$, but in that case the Greek aspiration is explained by the presence of an Indo-European aspirate and not by the effects of a laryngeal. We therefore believe that cannot be used as conclusive Greek evidence for aspiration caused by a laryngeal.

\section{Conclusion.}

We analysed 8 recent examples commonly used to prove laryngeal aspiration in Greek. We have shown that in three cases the evidence of aspiration cannot be sustained because of the cognates in other lan-

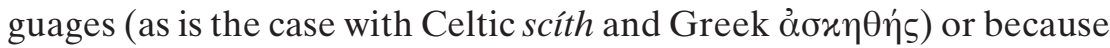
of the evolutions that the acceptance of aspiration presupposes (as is

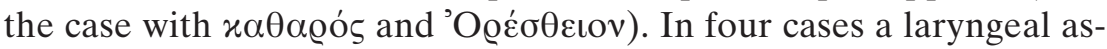
piration can be accepted (oĩ $\sigma \theta \alpha$, xó $\gamma \chi 0 \varsigma, \mu o ́ \theta o \varsigma$ and maybe also $\sigma \varphi \eta v$ ), although in all cases other explanations are possible and some leveling is needed (as is the case in $\sigma \varphi \eta v$ where the full grade of the nominative and the aspiration of the casus recti were supposedly generalised throughout the declension). In the instances with initial $s$ - the problem of the aspiration remains undecided as the examples can have received their aspiration by the effects of Siebs's Law, which is especially the case for $\sigma \varphi \alpha \dot{\lambda} \lambda \omega \omega$. That last example can also be explained from an entirely different (and non-laryngealistic) etymology as well. We believe that these four examples are not enough to prove the existence of laryngeal aspiration in Greek, especially in light of the evidence against it (which we discuss elsewhere). Our most important objection against the aspiration, is that accepting aspiration assumes that Greek generalised aspirated and non-aspirated forms without any clear indication as to which circumstances lead to which treatment. ${ }^{26}$

25 If Greek $\sigma \varphi \alpha \dot{\lambda} \lambda \omega \omega$ is no longer linked with Sanskrit skhalati and Armenian sxalem, theoretically a reconstruction $* s k^{h} a l$ is also possible.

26 Post script: only after finalising this article we came across the article by A. Willi in IF 115 (2010) in which he argued for aspirating effect of $* h_{2}$ on a preceding $r$ in Greek and have therefore not been able to treat or use that material here. 
Bibliography

Ascoli, G., 1868a, Zur lateinischen vertretung der indogermanischen aspiraten. KZ 17,241-281.

-, 1868b, Zur lateinischen vertretung der indogermanischen aspiraten. KZ 17,321352.

Aura Jorro, F., 1999, Diccionario griego-español, diccionario micénico. Madrid. (2 volumes)

Austerfjord, A., 1979, Zur Vorgeschichte des germanischen starken Präteritums. KZ 84,208-215.

Bally, C. - Gautier, L., 1922, Recueil des publications scientifiques de Ferdinand de Saussure. Genève.

Bammesberger, A., 1984, Studien zur Laryngaltheorie. Göttingen.

Barrack, C., 2002, The Glottalic Theory: a negative appraisal. IF 107, 76-98.

-, 2003, The Glottalic Theory revisited: a negative appraisal. Part II: The typological fallacy underlying the Glottalic Theory. IF 108, 1-16.

Beekes, R., 1969, The Development of the Proto Indo European Laryngeals in Greek. Paris - The Hague.

-, 1985, The origins of the Indo-European noun-inflection. Innsbruck.

-, 1988a, Laryngeal developments, a survey. In: Bammesberger, A. Die Laryngaltheorie und die Rekonstruktion des indogermanischen Laut- und Formensystems, Heidelberg, 1988, 59-105.

-, 1988b, A Grammar of Gatha Avestan. Leiden.

-, 1989, Old Persian p0im. MSS 50, 7-13.

-, 1995, Comparative Indo European Linguistics: An Introduction. AmsterdamPhiladelphia.

-, 1998, Een nieuw Indo-Europees etymologisch woordenboek. KNAW 61,9.

-, 2010, Etymological Dictionary of Greek. 2 volumes. Leiden.

Benveniste, E., 1935, Origines de la formation des noms en indo-européen. Paris.

Bezzenberger, A., 1908, Ar. pánthās und seine Flexion. KZ 42,384-385.

Brixhe, C., 1996, Phonétique et phonologie du grec ancien. Quelques grandes questions. Leuven.

Brugmann, K., 1886, Grundriss der vergleichenden Grammatik der indogermanischen Sprachen. Erster Band: Einleitung und Lautlehre. Strassburg.

-, 1889, Grundriss der vergleichenden Grammatik der indogermanischen Sprachen. Zweiter Band, Erste Hälfte: Wortbildungslehre, Stammbildungslehre, Flexionslehre. Strassburg.

-, 1892, Grundriss der vergleichenden Grammatik der indogermanischen Sprachen. Zweiter Band, Zweite Hälfte: Wortbildungslehre, Stammbildungslehre, Flexionslehre. Strassburg.

-, 1922, Kurze vergleichende Grammatik der indogermanischen Sprachen. Berlin.

Buck, C., 1904, A Grammar of Oscan and Umbrian. Boston.

-, 1955, Comparative grammar of Latin and Greek. Chicago.

Bugge, S., 1893, Beiträge zur etymologischen erläuterung der armenischen sprache. KZ 32,1-87.

Burrow, T., 1955, The Sanskrit language. London. 
-, 1957, An archaic verbal termination in early Indo-Iranian. IIJ 1,61-76.

-, 1979, The problem of shwa in Sanskrit. Oxford.

Çabej, E., 1980. Lautgeschichte und Etymologie im Bereich des Albanischen. In:

Peters, M. - Mayrhofer, M. - Pfeiffer, O. (ed), Lautgeschichte und Etymologie, Akten der VI Fachtagung der Indogermanischen Gesellschaft, Wiesbaden, 1980, 20-49.

Chantraine, P., 1928, Sur le rôle de l'élargissement ē/ō dans la conjugaison grecque. BSL 28,9-39.

-, 1932, Deux notes sur des formes verbales grecques. BSL 33,77-90.

-, 1933, La formations des noms en grec. Paris.

-, 1945, Morphologie historique du grec. Paris.

-, 1968-1974, Dictionnaire étymologique de la langue grecque. Paris.

Clackson, J., 1994, The linguistic relationship between Armenian and Greek. Oxford - Cambridge, MA.

-, 2007, Indo-European linguistics. Cambridge.

Cowgill, W., 1965, Evidence in Greek. In: Winter, W. (ed) Evidence for Laryngeals, The Hague, 1965, 142-180.

Curtius, G., 1853, Die aspiraten der indogermanischen sprachen. KZ 2, 321-337.

-, 1873, Grundzüge der griechischen Etymologie. Leipzig.

De Decker, F., 2010, What is the Greek counterpart of Sanskrit th? Handout and lecture at the conference Greek and Latin from an Indo-European Perspective 3, Bratislava, July 8-10 th 2010.

-, ftc a, Are Latin pons and pontifex evidence for an inherited i stem? JIES 40.

-, ftc b, To what extent does Stang's Law apply to laryngeals?

-, ftc c, What are the Greek and Latin counterparts of Sanskrit panthāh, manthāh and sakhā?

-, ftc d, What is the Greek counterpart of Sanskrit th? (written version of De Decker 2010).

De Lamberterie, C., 1974, Les occlusives sonores aspirées de l'arménien. REArm. 10,39-44.

Derksen, R., 2008, Etymological Dictionary of the Slavic Inherited Lexicon. Leiden.

De Vaan, M., 2008, Etymological dictionary of Latin and the other Italic languages. Leiden.

De Vries, J., 1962, Altnordisches etymologisches Wörterbuch. Leiden.

Eichner, H., 1972, Hethitisch mēhhhur. MSS

Elbourne, P., 1998, Proto-Indo-European voiceless aspirates. KZ 111,1-30.

-, 2000, Plain voiceless stop plus laryngeal in Proto-Indo-European. KZ 113,2-30.

-, 2001, Aspiration by s and devoicing of Mediae Aspiratae. KZ 114,197-219.

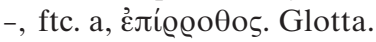

-, ftc. b, A rule of deaspiration in Greek.

Ernout, A. - Meillet, A., 1967, Dictionnaire étymologique de la langue latine. Paris (4ième ouvrage augmenté).

Euler, W., 1979, Indoiranisch-griechische Gemeinsamkeiten der Nominalbildung und deren indogermanische Grundlagen. Innsbruck.

Feist, S., 1888, Grundriss der gotischen Etymologie. Straßburg. 
Fortson, B., 2004, Indo-European language and culture, an introduction. Oxford.

Frisk, H., 1936, Suffixales th im Indogermanischen. Göteborg Högskolas Årsskrift 42,3-46.

-, 1960-1974, Griechisches etymologisches Wörterbuch. Heidelberg.

Furnée, E., 1972, Die wichtigsten konsonantischen Erscheinungen des Vorgriechischen. Amsterdam-Paris.

Grammont, M., 1948, Phonétique du grec ancien. Paris.

Graßmann, H., 1863a, Über die aspiraten und ihr gleichzeitiges vorhandensein im an- und auslaute der wurzeln. KZ 12,81-110.

-, 1863b, Über das ursprüngliche vorhandensein vom wurzeln, deren anlaut und auslaut ein aspirate enthielt. KZ 12,110-138.

-, 1873, Wörterbuch zu Rig Veda. Leipzig.

Greppin, J., 1982, The reflex of the Indo-European voiceless aspirates in Armenian. Mijazgayin Hayerenagitakan Gitazolov, Erevan, 35-48.

Hackstein, O., 2002, Die Sprachform der homerischen Epen. Wiesbaden.

Haug, D., 2003, Review Hackstein 2002. BMCR 2003. 06. 31.

Hiersche, R., 1964, Untersuchungen zur Frage der Tenues Aspiratae im Indogermanischen. Wiesbaden.

Hirt, H., 1912, Handbuch der griechischen Laut- und Formenlehre. Heidelberg.

-, 1921, Indogermanische Grammatik. Teil II, der indogermanische Vokalismus. Heidelberg.

-, 1927, Indogermanische Grammatik. Teil III, das Nomen. Heidelberg.

Hoenigswald, H., 1965, Evidence in Indo-Iranian. In: Winter, W. (ed) Evidence for Laryngeals, The Hague, 1965, 93-99.

Hofmann, J., 1950, Etymologisches Wörterbuch des Griechischen. München.

Holst, J., 1998, Ein bisher unentdecktes Lautgesetz im Albanischen und damit im Zusammenhang stehende Fragen. KZ 111, 83-98.

Hübschmann, H., 1882, Armeniaca III. ZDMG 36, 115-134.

-, 1883, Armenische Studien I. Grundzüge der armenischen Etymologie. Leipzig.

-, 1897, Armenische Grammatik. Teil I Armenische Etymologie. Leipzig.

Jamison, S., 1983, Function and Form of the áya formations. Göttingen.

Kloekhorst, A. 2008, The Inherited Hittite Lexicon. Leiden.

-, ftc, Weise's Law: Depalatalization of Palatovelars before *r in Sanskrit.

Klingenschmitt, G., 1982, Das altarmenische Verbum. Wiesbaden.

Kluge, F., 1882, Sprachhistorische Miscellen. PBB 8,506-539.

-, 1883. Zur altgermanischer Sprachgeschichte. KZ 26,68-103.

-, 1899, Etymologisches Wörterbuch der deutschen Sprache. Strassburg. (now 24th reprint)

Kuhn, A., 1852, Über das alte s und einige damit verbundene lautentwicklungen. KZ 1,270-277.

-, 1854a, Die aspirationen stummer consonanten. KZ 3,321-331.

-, 1854b, Über das alte $\mathrm{s}$ und einige damit verbundene lautentwicklungen. KZ 3,426-440.

Kühner, R. - Blass, F., 1890, Ausführliche Grammatik der griechischen Sprache. 1: Formenlehre. Hannover.

Kuiper, F., 1934, Die indogermanischen Nasalpräsentia. Amsterdam. 
-, 1942, Notes on Vedic noun inflection. KNAW 5,4, 161-255.

-, 1957, Avestan Mazdā. IIJ 1,86-95.

-, 1966, Review Hiersche 1964. IIJ 9,218-227.

Kuryłowicz, J., 1927, Les effects du ə en indo-iranien. Prace Filologiczne 11, 201-243.

-, 1927/8, ə indo-européen et h hittite. In: Symbolae grammaticae in honorem Ioannis Rozwadowski, Cracow, 1927/8, 95-104.

-, 1928, Le type védique gṛbhāyati. In: Meillet, A., Étrennes de linguistique offertes par quelques amis à Émile Benveniste, Paris, 1928, 51-62.

-, 1935, Études indo-européennes. Wrocław.

-, 1956, L'apophonie en indo-européen. Wrocław.

-, 1968, Indogermanische Grammatik. Teil II, Ablaut. Heidelberg.

Lazzeroni, R., 1998, "Sanskrit”. In: Ramat, P. - Giacalone Ramat, A., The IndoEuropean Languages, London, 1998, 98-124.

Lehmann, W., 1959, Proto-Indo-European Phonology. 3 Volumes. Austin.

Lejeune, M., 1972, Phonétique historique du mycénien et du grec ancien. Paris.

Lewis, C. - Short, C., 1891, A Latin dictionary. Oxford.

Lubotsky, A., 1981, Review Burrows 1979. Lingua 55,75-95.

-, 1989, The Vedic áya formations. IIJ 32, 89-113.

-, 1995, Sanskrit h <*dh, bh. In: N.V. Gurov and Ja.V. Vasil'kov (ed.), Sthāpakašrāddham, Professor G.A. Zograf Commemorative Volume, St. Petersburg, 1995, 124-144.

-, 1997, The Indo-Iranian reflexes of PIE *CRHUV. In: Lubotsky, A. Sound Law and Analogy. Papers in honor of Robert S.P. Beekes on the occasion of his 60th birthday, Amsterdam, 1997, 139-154.

-, ftc a, The Inherited Lexicon of Indo-Iranian. Leiden Indo-European Etymological Dictionaries Series.

-, ftc b, Historical Phonology of Indo-Iranian. To appear in Fritz, M. - Klein, J. Indo-European Linguistics.

Macdonell, A., 1910a, A Vedic reader for students. Oxford.

-, 1910b, Vedic Grammar. Leipzig.

-, 1916, A Vedic Grammar for Students. Oxford.

-, 1927, A Sanskrit Grammar for Students. Oxford.

Mallory, J. - Adams, D. (eds.), 1997, Encyclopedia of Indo European Culture. London-Chicago.

Mallory, J. - Adams, D., 2006, The Oxford introduction to Proto-Indo-European and the Proto-Indo-European world. Oxford.

Martirosyan, H., 2008, Studies in Armenian Etymology with special Emphasis on Dialects and Culture Indo-European Heritage. PhD. Thesis at Leiden University.

-, 2010, Etymological Dictionary of the Inherited Armenian Lexicon. Leiden.

Masica, C., 1991, The Indo-Aryan Languages. Cambridge.

Matzinger, J., 2005, Untersuchungen zum altarmenischen Nomen. Die Flexion des Substantivs. MSS Beiheft. Dettelbach.

Mayrhofer, M., 1953, Kurzgefasstes etymologisches Wörterbuch des Altindischen A concise etymological Sanskrit dictionary. Heidelberg. 
-, 1957, Kurzgefasstes etymologisches Wörterbuch des Altindischen - A concise etymological Sanskrit dictionary. Heidelberg.

-, 1976, Kurzgefasstes etymologisches Wörterbuch des Altindischen - A concise etymological Sanskrit dictionary. Heidelberg.

-, 1978, Sanskrit-Grammatik mit sprachvergleichenden Erläuterungen. Berlin.

-, 1981a, Ferdinand de Saussure. Nach hundert Jahren. Sitzungsberichte der Heidelberger Akademie der Wissenschaften, 7-38.

-, 1981b, Laryngalreflexe im Indo-Iranischen. ZPhon 34,427-438.

-, 1992, Etymologisches Wörterbuch des Altindoarischen. Band I. Heidelberg.

-, 1996, Etymologisches Wörterbuch des Altindoarischen. Band II. Heidelberg.

-, 2001, Etymologisches Wörterbuch des Altindoarischen. Band III. Heidelberg.

-, 2004, Die Hauptprobleme der indogermanischen Lautlehre seit Bechtel. Wien.

-, 2005, Die Fortsetzung der indogermanischen Laryngale im Indo-Iranischen. Wien.

-, 2006, Einiges zu den Skythen, ihrer Sprache, ihrem Nachleben. Wien.

-, 2009 Indogermanistik heute. Über Darstellungen und Einführungen von den Anfängen bis in die Gegenwart. Wien.

Meid, W., 1988, Einige persönliche und sachliche Bemerkungen zur Laryngaltheorie. In: Bammesberger, A. Die Laryngaltheorie und die Rekonstruktion des indogermanischen Laut- und Formensystems, Heidelberg, 1988,333-352.

Meier-Brügger, M., 1992, Griechische Sprachwissenschaft. Zwei Bände. Berlin.

-, 2003, Indo-European Linguistics. Berlin.

Meillet, A., 1894, De quelques difficultés de la théorie des gutturales indo-européennes. MSL 8, 277-304.

-, 1903, Esquisse d'une grammaire comparée de l'arménien classique. Wien.

-, 1913, Aperçu d'une histoire de la langue grecque. Paris.

-, 1927/8, Un suffixe indo-européen méconnu. In: Symbolae grammaticae in honorem Ioannis Rozwadowski, Cracow 1927/8, 105-108.

-, 1928, Esquisse d'une histoire de la langue latine. Paris.

-, 1930, De la valeur des sourdes aspirées indo-européennes. In: Bogholm, N. Brusendorff, A., A grammatical miscellany offered to Otto Jespersen on his seventieth birthday, Copenhagen, 1930, 341-343.

-, 1936, Les sourdes aspirées en arménien. BSL 36,109-120.

Meillet, A. - Vendryès, J., 1927, Traité de grammaire comparée des langues classiques. Paris.

Meiser, G., 1999, Historische Laut- und Formenlehre der lateinischen Sprache. Darmstadt.

Melchert, C., 1984, Studies in Hittite Historical Phonology. Göttingen.

Monier Williams, M., 1899, A Sanskrit-English dictionary, etymologically and philologically arranged with special reference to cognate Indo-European languages. Oxford.

Narten, J., 1960, Das vedische Verbum math-. IIJ 4, 121-135.

-, 1982, Die vedischen Präsensstämme hṛnāya, hṛnīya und Verwandtes. MSS 41,139-149.

Nowicki, H., 1976, Die neutralen s Stämme im indo-iranischen Zweig der Indogermanischen. Würzburg. 
Pape, W. - Benseler, G., 1863-1870, Wörterbuch der griechischen Personennamen. Braunschweig.

Pedersen, H., 1893, r/n stämme. KZ 32,240-273.

-, 1926, La cinquième déclinaison latine. Copenhagen.

Perpillou, J., 1973, Les substantifs grecs en عús. Paris.

Peters, M., 1980, Untersuchungen zur Vertretung der indogermanischen Laryngale im Griechischen. Wien.

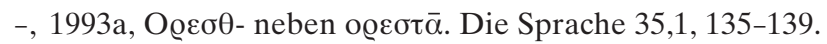

-, 1993b, Beiträge zur griechischen Etymologie. In: Isebaert, L. Miscellanea Linguistica Graeco-Latina, Namur, 1993, 85-113.

Pisani, V., 1973, Manuale storico della lingua greca. Edizione riveduta con un' appendice: il miceneo di C. Milani. Brescia.

Polomé, E., 1965, The Laryngeal Theory so far: a critical bibliographical survey. Winter, W. Evidence for Laryngeals, The Hague, 1965, 9-78.

Rasmussen, J., 1989, Die Tenues Aspiratae, Dreiteilung oder Vierteilung des indogermanischen Plosivsystems und die Konsequenzen dieser Frage für die Chronologie einer Glottalreihe. In: Vennemann, T., The New Sound of IndoEuropean: Essays in Phonological Reconstruction, Berlin, 1989,153-176.

Renou, L., 1952, Grammaire de la langue védique. Lyon- Paris.

Rix, H., 1976, Historische Grammatik des Griechischen. Laut- und Formenlehre. Darmstadt.

Rix, H. et alii, 2001, Lexikon der indogermanischen Verben. Wiesbaden.

Ruijgh, C., 1967, Études du grec mycénien. Amsterdam.

-, 1978, Review Rix 1976. Mnemosyne IV 31,3.298-307.

-, 1988, Les laryngales en grec préhistorique. In: Bammesberger, A. Die Laryngaltheorie und die Rekonstruktion des indogermanischen Laut- und Formensystems, Heidelberg, 1988, 433-469.

Scardigli, P., 1973, Die Goten. Sprache und Kultur. München.

Schindler, J., 1967, Das indogermanische Wort für Erde und die dentalen Spiranten. Die Sprache 13,190-205.

-, 1969, Die indogermanischen Wörter für "Vogel" und "Ei". Die Sprache 15,2,144-167.

Schmidt, G., 1973, Die iranischen Wörter für "Tochter" und "Vater" und die Reflexen des interkonsonantischen H (ə) in den indogermanischen Sprachen. KZ 87,36-83.

Schmidt, J., 1885, Indogermanisches ō aus ōi in der nominalflexion. Mit excurs: Zur bildung des nominativus singularis. KZ 27,369-397.

Schmitt, R., 1977, Einführung in die griechischen Dialekte. Darmstadt.

Schrijver, P., 1991, The Reflexes of the Proto-Indo-European Laryngeals in Latin. Amsterdam-Atlanta.

Schulze, W., 1913, Gr. бчүvóлоv૬. KZ 45, 190-191.

Schwyzer, E., 1939, Griechische Grammatik, auf der Grundlage von Karl Brugmanns griechischer Grammatik. München.

Seebold, E., 1980, Etymologie und Lautgesetz. In: Peters, M. - Mayrhofer, M. Pfeiffer, O. (ed), Lautgeschichte und Etymologie, Akten der VI Fachtagung der Indogermanischen Gesellschaft, Wiesbaden, 1980, 431-484. 
Siebs, T., 1900, Anlautstudien. KZ 37,277-324.

Sihler, A., 1995, A new comparative grammar of Greek and Latin. Oxford.

Smyth, H., 1956, Greek Grammar. Revised by Gordon Messing. Cambridge, MA.

Stang, C., 1949, A quoi correspond en germanique le th sanskrit? NTS 15,335-342.

Szemerényi, O., 1973, La théorie laryngale de Saussure à Kuryłowicz, essai de reévaluation. BSL 68, 1-73.

-, 1975, Rekonstruktion in der indogermanischen Flexion, Prinzipien und Probleme. In: Rix, H., 1975 (ed.), Flexion und Wortbildung. Akten der V. Fachtagung der Indogermanischen Gesellschaft, Wiesbaden, 325-345.

-, 1980, Einführung in die vergleichende Sprachwissenschaft. Wiesbaden.

Thumb, A., 1913, Über die Behandlung der Lautgruppe - $\sigma \theta$ - in den nordwestgriechischen Dialekten. IF 31,222-229.

Thumb, A. - Kieckers, E., 1932, Handbuch der griechischen Dialekte. Zweite erweiterte Auflage von E. Kieckers. Heidelberg.

Thumb, A. - Scherer, A., 1959, Handbuch der griechischen Dialekte. Zweiter Teil. Heidelberg.

Tichy, E., 1985, Avestisch pitar/ptar: zur Vertretung interkonsonantischer Laryngale im Indo-iranischen. MSS 45, 229-244.

-, 2009, Indogermanisches Grundwissen für Studierende sprachwissenschaftlicher Disziplinen. Bremen.

Uhlenbeck, C., Kurzgefasstes Wörterbuch der gotischen Sprache. Amsterdam.

-, 1898a, Kurzgefasstes etymologisches Wörterbuch der altindischen Sprache. Amsterdam.

-, 1898b, A manual of Sanskrit phonetics, in comparison with the Indo-Germanic mother tongue, for students of Germanic and Classical Philology. New Delhi.

-, 1902/3, Die vertretung der Tenues Aspiratae im lateinischen. IF 13,213-219.

Untermann, J., 2000, Wörterbuch des Oskisch-Umbrischen. Heidelberg.

Van den Bossche, F., 1999, A Reference Manual of Middle Prākrit Grammar. The Prākrits of the Dramas and the Jain Texts. Ghent.

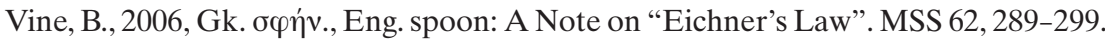

-, ftc. On dissimilatory $\mathrm{r}$ loss in Greek.

Wackernagel, J., 1894, Altindische Grammatik, I. Lautlehre. Göttingen.

-, 1895, Miszellen zur griechischen Grammatik, 30. die medialendungen mit $\sigma \theta$. KZ 33,57-61.

-, 1897, Vermischte Beiträge zur griechischen Sprachkunde. Programm zur Rektoratsfeier der Universität Basel. Basel

-, 1927/8, Indo-Iranica 1. pánthah “Weg”. KZ 55,104-109.

Wackernagel, J. - Debrunner, A., 1930, Altindische Grammatik, III. Nominalflexion- Zahlwort - Pronomen. Göttingen.

Wackernagel, J. - Debrunner, A. - Renou, L., 1957, Altindische Grammatik. With a new introduction on the Lautlehre. Göttingen.

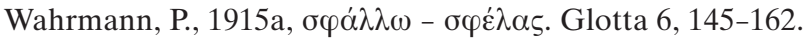

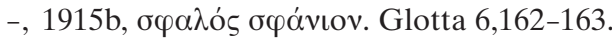

Walde, A., 1905, Lateinisches Etymologisches Wörterbuch. Heidelberg.

Walde, A. - Hoffmann, J., 1937, Lateinisches etymologisches Wörterbuch. Heidelberg. 
Walde, A. - Pokorny, J. 1927, Indogermanisches etymologisches Wörterbuch. Berlin.

Watkins, C., 1968, Indogermanische Grammatik. Teil III. Heidelberg.

Weise, O., 1881, Ist anlautendes $\gamma$ vor $\lambda$ abgefallen? BB 6, 105-118.

Weiss, M., 2009, Outline of the Historical and Comparative Grammar of Latin. Ann Arbor.

Werba, C., 1996, Verba indoarica: die primären und sekundären Wurzeln der Sanskrit-Sprache. Wien.

Whitney, W., 1879, A Sanskrit Grammar, including both the classical language, and the older dialects, of Veda and Brahmana. Bibliothek indogermanischer Grammatiken Band II. Leipzig.

Wodtko, D. - Irslinger, B. - Schneider, C., 2008, Nomina im indogermanischen Lexikon. Heidelberg.

Universiteit Hasselt

Filip De Decker

Centre for Applied Linguistics

BE-3590 Diepenbeek

Belgium

filipdedecker9@gmail.com 